\title{
Mitral valve repair in patients with rheumatic
} mitral insufficiency. Twenty years of techniques and results

\author{
Plástica da valva mitral em pacientes com insuficiência mitral reumática. Técnicas e resultados de \\ 20 anos
}

Pablo Maria Alberto POMERANTZEFF ${ }^{1}$, Carlos Manuel de Almeida BRANDÃO², Osanan Amorim LEITE FILHO², Marco Antônio Vieira GUEDES ${ }^{4}$, Marcos Floripes da SILVA ${ }^{5}$, Max GRINBERG ${ }^{6}$, Noedir Antônio Groppo STOLF ${ }^{7}$

RBCCV 44205-1122

\section{Abstract}

Objective: Mitral valve repair in rheumatic patients is still a challenge. The aim of this study is to assess the results of mitral valve repair in rheumatic patients with rheumatic mitral insufficiency.

Methods: 330 patients with rheumatic mitral insufficiency who had undergone mitral valve repair in the Heart Institute HC-FMUSP were assessed retrospectively, between 1985 and 2005. The mean age was $26.9 \pm 15.4$ years and $57.6 \%$ were female. On preoperative assessment, $39.5 \%$ of patients were in NYHA functional class IV. The most common techniques for repair employed were bovine pericardial strip annuloplasty in $48.4 \%$ patients and Carpentier ring annuloplasty in $\mathbf{2 2 . 6 \%}$. Shortening of chordae $(20 \%)$ and papillary muscle splitting $(\mathbf{1 7 . 8 \% )}$ were the most common associated techniques performed. Tricuspid valve repair $(26.7 \%)$ and aortic valve replacement (27.2\%) were the most common associated procedures.

Results: The hospital mortality was $0.9 \%$ (three patients), two of them children with active rheumatic fever. Linearized rates of thromboembolism, endocarditis, reoperation and late death were $0.2 \%, 0.2 \%, 3.5 \%$ and $0.5 \%$ patients-year, respectively. Actuarial survival in 20 years was $86.4 \pm 6.6 \%$.

1. Associated Professor of the Thoracic and Cardiovascular Surgery Discipline at FMUSP; Director of the Cardiac Valve Diseases Surgery Unit at InCor-HC FMUSP.

2. PhD in Medicine at FMUSP; Assistant Physician at InCor-HC FMUSP.

3. Postgraduation in Cardiovascular Surgery at FMUSP; Fellowship in Valve Surgery at InCor-HC FMUSP.

4. Specialist in Cardiovascular Surgery of BSCVS; Postgraduation in Cardiovascular Surgery at FMUSP.

5. Cardiovascular Surgeon at Marcílio Dias Hospital.

6. Full Professor at FMUSP; Director of Clinics Unit of Valve Diseases at InCor-HC FMUSP.

7. Titular Professor of the Cardiovascular Surgery Discipline at FMUSP; Director of Surgery Division of InCor-HC FMUSP.
Freedom from reoperation in 20 years was $30.3 \pm 11.1 \%$.

Conclusion: Mitral valve repair in rheumatic patients is a feasible procedure in correction of mitral insufficiency with low operative mortality.

Descriptors: Mitral valve/surgery. Mitral valve insufficiency/surgery. Rheumatic fever.

\section{Resumo}

Objetivo: A plástica da valva mitral em pacientes reumáticos permanece um desafio. $O$ objetivo deste estudo é analisar a técnica e os resultados da plástica da valva mitral em pacientes com insuficiência mitral reumática.

Métodos: Foram analisados, retrospectivamente, 330 pacientes portadores de insuficiência mitral reumática submetidos à plástica da valva mitral no Instituto do Coração do HC-FMUSP, entre 1985 e 2005. A idade média foi de 26,9 $\pm \mathbf{1 5 , 4}$ anos e $57,6 \%$ dos pacientes eram do sexo feminino. No pré-operatório, $39,5 \%$ dos pacientes estavam em classe funcional IV. As técnicas de plástica mais comumente utilizadas foram a anuloplastia posterior com tira de pericárdio bovino em $\mathbf{4 8 , 4 \%}$ dos pacientes e a anuloplastia com anel de Carpentier em 22,6\%. As técnicas associadas

This study was carried out at Heart Institute at HC-FMUSP, São Paulo, SP, Brazil.

Correspondence address:

Pablo M. A. Pomerantzeff.

Av. Dr. Enéas de Carvalho Aguiar, 44. Surgical Dept. -

São Paulo, SP, Brazil - CEP: 05403-100.

E-mail: dcipablo@incor.usp.br 
foram empregadas em $55,2 \%$ dos pacientes, sendo as mais comuns: encurtamento de cordas $(20 \%)$ e papilarotomias múltiplas $(17,8 \%)$. Plástica da valva tricúspide $(26,7 \%)$ e substituição da valva aórtica $(27,2 \%)$ foram os procedimentos associados mais frequentes.

Resultados: A mortalidade hospitalar foi $0,9 \%$ (três pacientes), sendo dois deles crianças em atividade reumática. As taxas linearizadas de tromboembolismo, endocardite, reoperação e óbito tardio foram de $0,2 \%, 0,2 \%, 3,5 \%$ e $0,5 \%$

\section{INTRODUCTION}

The techniques of mitral valve repair are procedures of choice in the surgical treatment of mitral valve disease, and are increasingly used in the surgical management of valvular diseases and preferable to valve replacement when technically feasible.

Knowledge of three-dimensional mitral valve anatomy and its work during the cardiac cycle, associated to the understanding of the mechanisms contributing to the valve dysfunction is critical to the success of the conservative mitral valve surgery.

Until now we could not find uniform results in the literature of mitral valve repair in patients with lesions resulting from rheumatic fever [1-3]. The explanation could be related to the interference of new rheumatic outbreaks in these patients. However, there is agreement on the lowest morbidity and mortality of patients undergoing mitral valve repair compared with valve replacement.

This study aims to analyze the 20-year late results of mitral valve repair in rheumatic patients, using various repair techniques.

\section{METHODS}

During the period from January 1985 to December 2005, 330 patients with rheumatic fever diagnosed with mitral failure underwent mitral valve repair at the Heart Institute of the Clinics Hospital of the Faculty of Medicine, University of São Paulo. The study was approved by the Scientific Committee of the Heart Institute and the Ethics Committee of the Clinics Hospital of the Faculty of Medicine, University of São Paulo.

The patients' ages ranged from 5 to 57 years, mean 26.9 \pm 15.4 years. One hundred and ninety $(57.6 \%)$ patients were female and 140 (42.4\%) were male.

The techniques of mitral valve repair were: posterior annuloplasty using bovine pericardial patch in 160 (48.4\%), Carpentier ring in 75 (22.6\%), posterior segmental annuloplasty in $32(9.7 \%)$, quadrangular resection of the posterior leaflet with plication of the ring in 23 (6.9\%), pacientes-ano, respectivamente. A sobrevida actuarial foi de $\mathbf{8 6 , 4} \pm \mathbf{6 , 6 \%} \mathrm{em} 20$ anos. A curva livre de reoperação foi de $30,3 \pm 11,1 \%$ em 20 anos.

Conclusões: A plástica da valva mitral em pacientes reumáticos é uma técnica factível na correção da insuficiência mitral, com baixa mortalidade operatória.

Descritores: Valva mitral/cirurgia. Insuficiência da valva mitral/cirurgia. Febre reumática.

posterior Shore annuloplasty in 12 (3.6\%), triangular resection of the anterior leaflet in eight (2.4\%), Kay in five (1.5\%), enlargement of the posterior leaflet using bovine pericardium in four (1.2\%), double- $\mathrm{U}$ as opposed in four (1.2\%), Reed in three (0.9\%), cleft suturing in two (0.6\%) and Puig-Massana ring in one $(0.3 \%)$. Associated techniques were used in 182 (55.2\%) patients, and the most frequent was cords shortening in $66(20 \%)$ cases. Other techniques used were: multiple papillectomy in 59 (17.8\%) cases, commissurotomy in 30 (9.1\%), smoothing of the posterior leflet in eight (2.4\%), resection of short strings in three $(0,9 \%)$, cusp repair in three $(0.9 \%)$, papillary muscle sliding in two $(0.6 \%)$ and transposition of chords in one $(0.3 \%)$.

Associated operations were performed in 219 (66.4\%) patients, 90 (27.2\%) aortic valve replacements, 88 (26.7\%) tricuspid valve repair, 23 (7\%) aortic valve repair, $10(3 \%)$ aortic commissurotomies, six (1.8\%) CABG and two (0.6\%) tricuspid valve replacements.

Regarding the functional class (New York Heart Association), 130 (39.5\%) patients were in functional class IV, 179 (54.3\%) in functional class III and 21 (6.2\%) in functional class II.

The postoperative follow-up was performed through hospital consultations or telephone interviews or using questionnaires sent by mail.

Data will be presented in accordance with the revised standards for data reporting and nomenclature. The survival actuarial and free from events were calculated using the Kaplan Meier [4] and compared by linear regression analysis. The linearized rates of events are expressed as a percentage of events per patient/year (\%/pat.-year).

\section{RESULTS}

The hospital mortality was $0.9 \%$ (three patients). The causes were low cardiac output in two (0.6\%) patients one was a child who was under rheumatic activity - and multiple organ failure in one (0.3\%) patient - with also a child under rheumatic activity.

In the late postoperative period, 177 (63\%) patients were 

results

in functional class I, 51 (18.1\%) were class II, 37 (13.2\%) were in functional class III and 16 (5.7\%) patients in functional class IV. The period of follow-up was 17,486 months/patients (88.3\% full).

Late mortality in this population was $2.8 \%$ (nine patients). Five patients died due to heart failure, two, sepsis and the other two the cause of death was unknown.

The linearized rates of the events reoperation, death, endocarditis, and thromboembolism are shown in Table 1. There was no hemolysis in this series of patients.

The actuarial survival in 20 years was $86.4 \pm 6.6 \%$ (Figure 1). The actuarial curves free from thromboembolism (Figure 2), reoperation (Figure 3) and endocarditis (Figure 4) were $99.7 \pm 0.3 \%, 30.3 \pm 11.1 \%$ and $95.6 \pm 4.3 \%$ in 20 years, respectively.

Table 1. Linearized rates of the events (late evolution).

\begin{tabular}{lc}
\hline Event & \% patients-year \\
\hline Reoperation & 3.5 \\
Death & 0.5 \\
Endocarditis & 0.2 \\
Thromboembolism & 0.2 \\
\hline
\end{tabular}

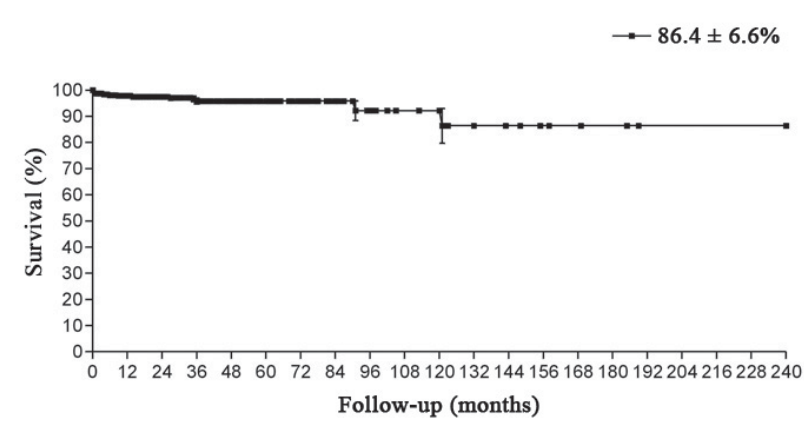

Fig. 1 - Actuarial survival at 20 years

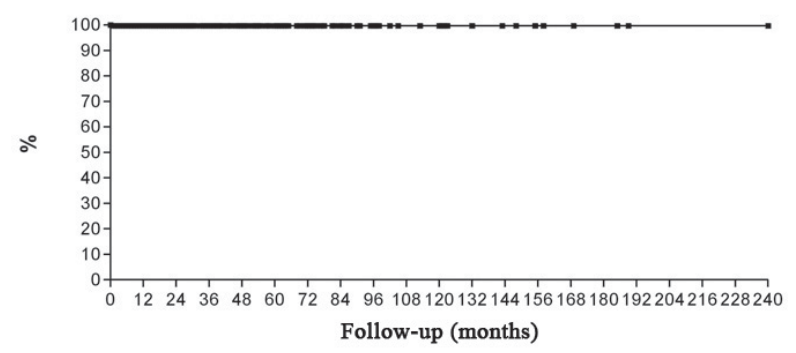

Fig. 2 - Actuarial curve free from thromboembolism

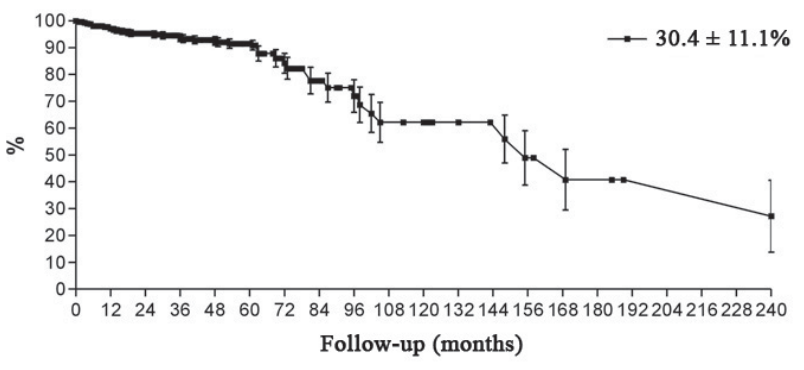

Fig. 3 - Actuarial curve free from reoperation

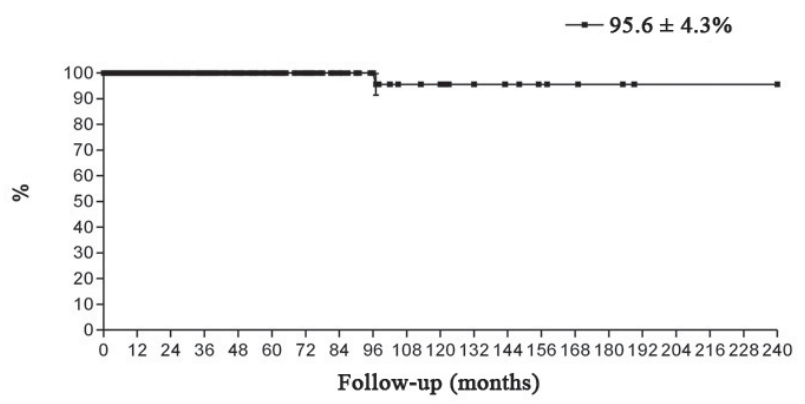

Fig. 4 - Actuarial curve free from endocarditis

\section{DISCUSSION}

A degenerative disease of the mitral valve is the most common cause of mitral failure in industrialized countries. In such cases, the mitral valve repair is the procedure of choice, with excellent late results [5,6]. However, in our country, rheumatic etiology is prevalent and, in this population, the long-term outcomes may be affected by the appearance of new outbreaks of the disease [7]. Despite this fact, every effort must be made in order to perform conservative treatment, since a large proportion of these patients are young and therefore subject to greater number of surgical interventions during evolution [8,9]. Other factors to be considered are the difficulty of anticoagulation of patients in our country and early calcification of bioprostheses in this age group.

Mitral valve repair in rheumatic patients have shown better outcomes than mitral valve replacement [10]. On the other hand, conservative surgery of the mitral valve in rheumatic patients is technically more difficult than in patients with degenerative valvular heart disease [11] and its outcomes depend on the degree of impairment of the valve at the time of surgical approach, that is, the worse the conditions at the time of reconstruction, the worse the outcome [12,13]. 

results

The valve repair requires the surgeon a perfect knowledge of anatomy and the multiplicity of existing techniques. Moreover, the evaluation of the leaflets, the subvalvular plane, the tendinae cords and papillary muscles should be performed in a systematic manner during surgery. The test with saline solution complements this analysis. Transesophageal Doppler echocardiography has contributed to the evaluation and intraoperative decision.

The choice of technique to be used for annuloplasty should take into account the valve change. Usually, the dilation of the mitral orifice affects only the posterior two thirds of the annulus, which corresponds to the area of the posterior leaflet. Several rings have been described, rigid or flexible, to remodel the mitral valve [2,14]. Loop et al. [15] prefer the use of the Carpentier ring to reduce the annulus. Although widely used, the rigid rings may have some problems, such as systolic anterior motion in $4 \%$ to $10 \%$ of cases, causing obstruction of the outflow tract of the left ventricle [16]. In our Service, we have used this technique preferably in the large dilated left ventricle and, in other situations where it is necessary to reduce the annulus, we used a bovine pericardium patch from trigone to trigone, with good late outcomes [17]. A bovine pericardium patch is flexible and does not interfere with the normal anatomy of the mitral annulus, which we now know is not flat and is changed during the different phases of the cardiac cycle.

However, other authors have used grafts from autologous tissue, such as the posterior leaflet of the tricuspid valve [18] and pericardium [19], in mitral valve repair in rheumatic patients, on which the shrinkage and low mobility are the primary findings.

The late results of mitral valve repair also depend on a good coaptation of the leaflets, that is, an area of adequate coaptation after valve repair. This good coaptation can be achieved with the help of the shortening of the chordae tendinae [20] or shortening of papillary muscles. Recently, in children, we have increased the use of sliding of both papillary muscles in order to proceed to the shortening of all the cords of the anterior leaflet.

The hospital mortality was $0.9 \%$, a low value when compared to international literature, which ranges from $2.6 \%$ to $3.6 \%$ [2,21]. In our country, Petrucci Jr et al. [22] reached a mortality rate of $0 \%$ in a small group of 23 rheumatic patients undergoing mitral valve repair. The late mortality of $3.2 \%$ with linear rate of $0.5 \%$ patient/years was also lower than that found in the literature [11,21].

The linearized rate of reoperation found of 3.5\% patients-years was similar to the literature [11] and higher when compared to patients with degenerative etiology [23]. A higher linearized rate of reoperation is expected, since the rheumatic etiology is a risk factor for reoperation due to outbreaks of rheumatic fever, which continually provoke structural changes in the mitral valve apparatus [24].
The rheumatic patients undergoing mitral valve repair showed low rates of complications (thromboembolism, endocarditis, and hemolysis) in the long-term. Such outcomes are similar to those found in the literature [11,25].

\section{CONCLUSION}

In conclusion, mitral valve repair is feasible in the correction of mitral failure of rheumatic etiology, with low operative mortality.

\section{REFERENCES}

1. Reed GE, Kloth HH, Kiely B, Danilowicz DA, Rader B, Doyle EF. Long-term results of mitral annuloplasty in children with rheumatic mitral regurgitation. Circulation. 1974;50(2 Suppl):II189-92.

2. Bernal JM, Rabasa JM, Vilchez FG, Cagigas JC, Revuelta JM. Mitral valve repair in rheumatic disease. The flexible solution. Circulation. 1993;88(4 Pt 1):1746-53.

3. Pomerantzeff PMA, Brandão CMA, Monteiro ACM, Nersessian AC, Zeratti AE, Stolf NAG, et al. Plástica da valva mitral: resultados tardios de 12 anos de experiência e evolução das técnicas. Rev Bras Cir Cardiovasc. 1994;9(1):22-8.

4. Akins CW, Miller DC, Turina MI, Kouchoukos NT, Blackstone EH, Grunkemeier GL, et al. Guidelines for reporting mortality and morbidity after valvular interventions. Eur J Cardiothorac Surg. 2008;33(4):523-8.

5. Espada R, Westaby S. New developments in mitral valve repair. Curr Opin Cardiol. 1998;13(2):80-4.

6. Gillinov AM, Cosgrove DM, Blackstone EH, Diaz R, Arnold $\mathrm{JH}$, Lytle BW, et al. Durability of mitral valve repair for degenerative disease. J Thorac Cardiovasc Surg. 1998;116(5):734-43.

7. Sousa Uva M, Dreyfus G, Rescigno G, al Aile N, Mascagni R, La Marra M, et al. Surgical treatment of asymptomatic and mildly symptomatic mitral regurgitation. J Thorac Cardiovasc Surg. 1996;112(5):1240-8.

8. Pomerantzeff PMA, Brandão CMA, Faber CN, Fonseca MH, Puig LB, Grinberg M, et al. Plástica da valva mitral: resultados aos 17 anos de experiência. Rev Bras Cir Cardiovasc. 1999;14(3):185-90. 
results

9. David TE. The appropriateness of mitral valve repair for rheumatic mitral valve disease. J Heart Valve Dis. 1997;6(4):373-4.

10. Shuhaiber J, Anderson RJ. Meta-analysis of clinical outcomes following surgical mitral valve repair or replacement. Eur J Cardiothorac Surg. 2007;31(2):267-75.

11. Antunes MJ, Magalhães MP, Colsen PR, Kinsley RH. Valvuloplasty for rheumatic mitral valve disease. A surgical challenge. J Thorac Cardiovasc Surg. 1987;94(1):44-56.

12. Pomerantzeff PMA, Brandão CMA, Faber CM, Grinberg M, Cardoso LF, Tarasoutchi F, et al. Plástica da valva mitral em portadores de febre reumática. Rev Bras Cir Cardiovasc. 1998;13(3):211-5.

13. Wang YC, Tsai FC, Chu JJ, Lin PJ. Midterm outcomes of rheumatic repair versus replacement. Int Heart J. 2008;49(5):565-76.

14. Carpentier A. La valvuloplastie reconstitutive: une nouvelle technique de valvuloplasty mitrale. Press Med. 1969;77(7):251-3.

15. Loop FD, Cosgrove DM, Stewart WJ. Mitral valve repair for mitral insufficiency. Eur Heart J. 1991;12(Suppl B):30-3.

16. Alvarez JM, Deal CW, Loveridge K, Brennan P, Eisenberg R, Ward $\mathrm{M}$, et al. Repairing the degenerative mitral valve: ten to fifteen year follow-up. J Thorac Cardiovasc Surg. 1996;112(2):238-47.

17. Pomerantzeff PM, Brandão CMA, Albuquerque JM, Pomerantzeff PY, Takeda F, Oliveira SA. Mitral valve annuloplasty with a bovine pericardial strip-18-year results. Clinics. 2005;60(4):305-10.
18. El Oumeiri B, Boodhwani M, Glineur D, De Kerchove L, Poncelet A, Astarci P, et al. Extending the scope of mitral valve repair in rheumatic disease. Ann Thorac Surg. 2009;87(6):1735-40.

19. Rankin JS, Sharma MK, Teague SM, McLaughlin VW, Johnston TS, McRae AT. A new approach to mitral valve repair for rheumatic disease: preliminary study. J Heart Valve Dis. 2008;17(6):614-9.

20. Shore DF, Wong P, Paneth M. Valve repair versus replacement in the surgical management of ruptured chordae. A postoperative echocardiographic assessment of mitral valve function. J Cardiovasc Surg (Torino). 1982;23(5):378-82.

21. Kumar AS, Talwar S, Saxena A, Singh R, Velayoudam D. Results of mitral valve repair in rheumatic mitral regurgitation. Interact Cardiovasc Thorac Surg. 2006;5(4):356-61.

22. Petrucci Jr O, Oliveira PPM, Silveira LM, Passos FM, Vieira RW, Braile DM. Resultados a médio prazo de anuloplastia com órtese maleável de pericárdio bovino na insuficiência mitral reumática. Rev Bras Cir Cardiovasc. 1999;14(2):105-8.

23. Brandão CMA, Guedes MAV, Silva MF, Vieira ML, Pomerantzeff PMA, Stolf NAG. Plástica da valva mitral com a técnica do "duplo teflon": resultados de 10 anos. Rev Bras Cir Cardiovasc. 2007;22(4):448-53.

24. Fernandez J, Joyce DH, Hirschfeld K, Chen C, Laub GW, Adkins MS, et al. Factors affecting mitral valve reoperation in 317 survivors after mitral valve reconstruction. Ann Thorac Surg. 1992;54(3):440-7.

25. Chauvaud S, Perier P, Touati G, Relland J, Kara SM, Benomar $\mathrm{M}$, et al. Long-term results of valve repair in children with acquired mitral valve incompetence. Circulation. 1986;74(3 Pt 2):I104-9. 